\title{
Sobukwe and the psychosocial
}

\section{Abstract}

The political writings of Robert Mangaliso Sobukwe, like those of Anton Muziwakhe Lembede and Steve Bantu Biko, are shot through with psychological notions (ideas of consciousness, mental emancipation, psychological enslavement, self-realization, the African personality, etc.). The use of such terms is not psychological in a strict disciplinary sense, yet it is nevertheless of crucial psychosocial relevance for a number of reasons. Firstly, such a borrowing of terms necessarily breaks down the partitioning of the psychical and the political. Secondly, by being extracted from the discourse of psychology and subjected to a psychosocial application, these terms are rendered politically operative and put to immediate socio-political use as part of the struggle against white supremacy. Thirdly, the psychological vernacular historically deployed by Sobukwe, Lembede and Biko, effectively called attention to aspects of the struggle not adequately foregrounded by political vocabularies of the time. It was in this way that the aligned discourses of African Nationalism and Black Consciousness as realized in the writings of Sobukwe, Lembede and Biko, sought to overcome an otherwise flawed mode of political resistance - the gradualist, petitioning stance of the African National Congress in the 1950s - with something altogether more radical.

\section{Introduction}

For some readers of PINS (Psychology in society), the relevance of the political legacy of Robert Sobukwe to the aligned fields of psychosocial studies and critical psychology is obvious. This seems particularly the case amidst mounting calls for properly de-colonising and
Derek Hook

Duquesne University, Pittsburgh, USA hookd@duq.edu

\section{Keywords:}

Sobukwe, Biko, Black Consciousness, consciousness, psychosocial studies 
African forms of psychology (Mhkize, 2004a; Cooper, 2013; Ratele, 2014). There are, after all, multiple currents within Sobukwe's thinking that might be profitably explored by psychosocial and critical psychology scholars. Sobukwe's idea of non-racialism as opposed to notions of multi-racialism (Dladla, 2014; Soske, 2014), makes for an obvious case in point, especially in respect of the ongoing necessity of research on racism in the post-apartheid context. The same holds for Sobukwe's thoughts on African Nationalism (Delport, 2014), his critique of white liberalism, and his repeated re-assertion - crucial for the subsequent development of the Black Consciousness Movement - of the importance of a consolidated (Pan)African identity (or "African personality") in the face of colonial oppression (Mangcu, 2012; Mabandu, 2013; wa Azania 2014). Nonetheless, the question of Sobukwe's particular value to what we might generally refer to as "the domain of the psychosocial" deserves further scrutiny. This is the objective of this paper.

How though might we define the purview of psychosocial studies? A psychosocial studies approach, says Saville-Young (2011), questions the traditional division of the personal and the social, jointly undermining notions of an inner reality (the psyche) and outer reality (the social) as separable categories of analysis. It argues instead for a psychosocial realm whereby the social and the psychological are involved in the simultaneous and ongoing construction of one another (see also Frosh, 2003, 2011). To this description I would add three qualifications. Firstly, the social is inevitably also the political, and as such the remit of the psychosocial necessarily includes an attention to what Judith Butler (1997) has referred to as the psychic life of power. The psychosocial, in this sense, can - or should - be considered as synonymous with the psycho-political. Secondly, despite the frequent use of psychoanalytic theory, the field of psychosocial studies entails a somewhat open-ended use of critical social theory (see for example Blackman, Cromby, Hook, Papadopoulos \& Walkderdine, 2008; Brown \& Stenner, 2009). It is bound neither by a given historical context nor by a single set of theoretical resources. It is as such open to application in diverse particular historical sites - such as that of the (post)apartheid South African context (Saville Young, 2011; Hook, 2013; Saville Young \& Jearey-Graham, 2015) - just as it is receptive to a variety of conceptual tools (see Frosh, 2015) that will enable it to advance novel forms of social, political and indeed psychosocial critique. Thirdly, the politicization that energized critical psychology in its deconstructive readings and ideological critiques of psychology, has in many respects been passed onto psychosocial studies which, as such, remains attentive to the perils of psychological reductionism, psychological imperialism and the uses of psychology in the interests of power (Owusu-Bempah \& Howit, 1995; Parker, 1999, 2002; Hook, 2004). What this means then is that as an emerging and by definition cross-disciplinary field, psychosocial studies allows then for a wide possible range of critical conjunctions between facets of the political and the experiential, the psychic and the structural. 
There are two routes we might take in pointing out the relevance of Sobukwe's work to psychosocial studies. A first, precursory, option involves foregrounding existing work within the broader remit of critical psychology that resonates with Sobukwe's critique of white supremacy. A second route involves developing a more detailed and specific response to this question, one that considers crucial aspects of the political and intellectual tradition that Sobukwe embodied. I will take up each of these questions in turn, pausing, along the way, to consider the importance of consciousness as a key political and psychosocial concept.

\section{Biko and a critical psychology of the postcolonial}

Regards the relevance of anti-colonial and anti-apartheid thinkers for critical psychology, we might opt simply to note that a bridgehead for work of this sort has already been established. This is certainly so in attempts to apply Frantz Fanon's (1986, 1990) work within the remit of anti-racist forms of psychological critique (Bulhan, 1979, 1985, 1999; Hook, 2004); in types of psychological analysis informed by the ideas of Black Consciousness (Manganyi, 1973, 1977, 1981); in liberation psychology (MartínBaró, 1994; Foster, 2004; Burton \& Osorio, 2011); in calls for a critical psychology of the postcolonial (Macleod \& Bhatia, 2007; Hook, 2012; Hook \& Truscott, 2013); in the project of developing properly African forms of the discipline (Akin-Ogundeji, 1991; 1993; Mhkize, 2004a, 2004b; Ratele, 2004, 2014; Cooper, 2013, 2014); and in the decolonising agenda apparent in forms of contemporary political and social psychology (Frosh, 2013; Kessi, 2013; Persram, 2013; Truscott \& Hook, 2014)1. Rather than repeating the debates in the above-cited literature regarding the influence of anti-colonial/anti-apartheid thinkers on contemporary forms of psychology, it perhaps suffices to note that PINS (Psychology in society has long since served as a home for such work (Nzimande, 1985; Couve, 1986; Ndlovu, 2010; Hayes, 2011; Manganyi, 2011) and to stress that facilitating critical trajectories of this sort falls well within the journal's given mandate of "foster[ing] a socio-historical and critical theory perspective by focussing on the theory ... of psychology in the southern African context”.

One should also note here a critical tradition that takes issue with psychology's colonising agenda in Africa in particular. As Amina Mama (1995) argues, empiricist psychology was one of the institutional bedrocks upon which the concepts of Africa and the African mind were historically constructed. Colonialism and apartheid were, indeed, strengthened by psychological treatises that started to emerge at the end of the 1800s (Vaughan, 1991; Dubow, 1995). Psychology, furthermore, was operationalized as a political tool in the service of white supremacy (Bulhan, 1981;

To this list we might add a series of recent psychosocial engagements with South Africa's apartheid past (Bowman, Duncan \& Sonn, 2010; Stevens and Laubscher, 2010; Duncan, Stevens \& Sonn, 2013; Stevens, Duncan \& Hook, 2013). 
Manganyi, 1985; Howitt \& Owusu-Bempah, 1994). Sobukwe's anti-colonial thinking is thus of considerable importance given that "in Africa ... psychological expertise was increasingly deployed, not merely to inferiorise and subordinate Africans but also to meet the needs of the late colonial and early post-colonial African economies for ... controllable workforces". (Mama, 1995: 39)

And yet the argument for the critical psychological relevance of Sobukwe's political thought - treated here as a formative component of the subsequent Black Consciousness Movement - can be more strongly made. For instance, the claim can be advanced that many political texts from the history of the liberation struggle are, in many ways, already qualified instances of psycho-social critique. How so? Well, inasmuch as they draw upon and work within the register of the psychological (via mentions of consciousness, mental emancipation, psychological enslavement, the envisioned self, African personality, etc.) to enforce and develop adaptive forms of political critique and resistance (Hook, 2005; Richards, 2011). Here no better example can be offered than the various formulations of the aims and agendas of Black Consciousness as offered by Biko (1978) and others. These concepts are worth briefly revisiting as a prelude to discussing the man who proved such an important influence on both upon Biko and the Black Consciousness movement - Sobukwe himself.

Biko, as is well known, called for psychological and cultural liberation as a necessary prerequisite for political freedom, declaring "mental emancipation as a precondition to political emancipation" (Biko, 1978: 29). "The interrelationship between the consciousness of the self and the emancipatory programme", he declared, "is of paramount importance" (Biko, 1978: 49). Biko's "psychosocial" account of Black Consciousness can be augmented by referring to a series of descriptions offered by proponents of the movement. For Arnold (1979: xxi) it was "the psychological battle for the minds of the black people" that made up the "pivotal psychological dimension to Black Consciousness's approach to emancipatory politics" (1979: 172). For Halisi (1991: 109), Biko was fundamentally concerned with relating psychological liberation to culture: "Biko considered the transformation of consciousness to be a catalyst for mass action". Turner and Alan (1978: 22) similarly note: "Biko ... always centres the possibility for change within the subjectivity of the oppressed person, and not simply within the South African economy or the hierarchy of the system". Speaking of "self-consciousness as force and reason of revolution", Turner (2008: 77-78) likewise observes that Biko "brought forth the re-discovery of self-consciousness as an objective force within the process of liberation". For Gibson (2008: 136) the consciousness-raising of Black Consciousness was "not merely a passing stage in the revolutionary process ... [but] an actuality in which the transformation of reality is grounded". Barney Pityana, Biko's collaborator and friend, develops this last point in a passage that is worth quoting at length: 
"To ask the right questions, to encourage a new consciousness, and to suggest new forms which express it, are the basic purposes of our new direction ... One has to take account of ... years of indoctrination starting from the first encounter of the white colonists with black tribesmen, when whites were set up as a standard .... The urgency of the moment is that we have to liberate the mind of the black man ... The first step is to make the black man see himself ... to remind him of his complicity in the crime of allowing himself to be misused and therefore letting evil reign supreme in the country of his birth. This is what we mean by an inward-looking process ... [B]lack people must build themselves into a position of non-dependence upon whites .... The way to the future is not through a directionless multiracialism but through a positive unilateral approach. Black man, you are on your own". (Pityana, cited in Woods, 1978: 37-39)

This montage of descriptions deserves to be supplemented by a stark autobiographical reflection offered by Biko:

\begin{abstract}
"Born shortly before 1948, I have lived all my conscious life in the framework of institutionalized separate development. My friendships, my love, my education, my thinking and every other facet of my life have been carved and shaped within the context of separate development. In stages during my life I have managed to outgrow some of the things the system taught me ... [W] hat I propose to do now is to take a look at those who participate in opposition to the system, not from a detached point of view but from the point of view of a black man, conscious of the urgent need for an understanding of what is involved in the new approach - 'black consciousness'”. (Biko, 1978: 27)
\end{abstract}

Not only does Biko impress upon us here the saturating influence of apartheid ideology, he also underlines the need for a type of de-indoctrination that takes the route of a committed and personalized political consciousness by way of response. In his commentary on this passage, Sanders (2002: 164) notes that for Black Consciousness "talk of resistance has no meaning when complicity is not negotiated". This complicity, argues Sanders (2002:178-179), is not only of the "conscious, analytical mind", but also of the psyche, one requiring "a psychic solution", a "coming to terms with the unconscious". Suffice to say then that a psychosocial dimension proves irreducible in each of the above descriptions of Black Consciousness.

\title{
Political consciousness and materialist psychology
}

The claim can of course be made that what Biko has in mind when invoking the notion of consciousness is a world away from what theorists and practitioners of psychology understand by the term. "Consciousness" in the context of sociology or critical theory - and 
arguably, for Biko also - is often used in a way synonymous with consciousness-raising (see Macey, 2000a), rather than referring to the contents or processes of perception (a typical understanding of the term in the history of psychology). Consciousness in the former context does not concern itself exclusively with the content of minds, and cannot by any means be reduced to the charge of psychological idealism, that is, the psychological concern with "what goes on in people's heads" (Parker, 2015). Such a view of consciousness, by contrast, has its roots in a Marxist - and thereby materialist - concern with political emancipation and agency (Macey, 2000a). It refers as such to a historically - and experientially-grounded mode of critical sensibility attuned to the omnipresence of relations of power, subjugation and oppression.

This being said, it is nonetheless worthwhile reflecting briefly on what philosophical and psychological ideas inform - or remain latent within - Biko's own particular use of the concept. Our first port of call here is Frantz Fanon, whose writing exercised such a prodigious influence on Biko, and whose theorization of consciousness is the subject of extended commentary by philosopher Lewis Gordon (1995: 32):

"[What Fanon] ultimately saw by the mid-fifties was that revolutionary considerations were needed for a human place in the story of self-consciousness that stands outside of white superiority and coloured inferiority. This is the thesis of $\mathbf{A}$ dying colonialism, were Fanon shows how a transformation of consciousness emerges through the mass mobilization in revolutionary praxis. One should bear in mind, however, that Fanon's thesis related to his appeal to humanism and humanization is premised upon the provision of the source of revolution being rooted in the situation and experience of the colonised - that is, the oppressed".

Several remarks follow from a reading of this passage. Consciousness is said to emerge in an eminently historical form, in a concrete political context, yet precisely via the mode of a humanizing self-consciousness that locates itself beyond the remit and interpellative force of white supremacy. Secondly, it is revolutionary, it arises through praxis and - this is the point I wish particularly to stress - it is rooted in the experience of the oppressed. That is to say, while political/sociological theorization of consciousness seem to operate in a different (historical, societal) register to psychological conceptualizations of the concept, such a theorization cannot bypass or preclude the psychological, as it entails the everyday perceptual, experiential and subjective aspects of a broader historical form of consciousness. Gibson (2003: 143) makes a similar point, stressing the role of a type of self-construction:

"in the philosophic language of Black skin white masks [Fanon] formulates Black selfconsciousness as an 'absolute intensity of beginning' from itself ... [i]t is Fanon's notion 
of the self-construction of the self. But rather than simply an individual will to liberty, Fanon's conception of self-construction ... is the coming to be of a new social individual".

More succinctly put: self-consciousness is itself one facet of a more global type of political consciousness ultimately inseparable from its social forms. This is why it is necessary to stress the phenomenological-existential dimension of Fanon's thought (Macey, 1999, 2000b), which so richly combines and overlays the domains of the experiential and political. It is, after all, precisely Fanon's project - particularly in Black skin white masks (1986) but also in The wretched of the earth (1990) - to complicate any such neat compartmentalization of the psychical and the structural, certainly so with respect to the issue of colonial violence. By the end of a reading of his analysis of colonial racism, these two facets, the psychological and the political cannot, in effect, be separated (Bhabha, 2004), a fact which makes Fanon - and by extrapolation as we shall see, Biko and Sobukwe - of paradigmatic importance for the discipline of psychosocial studies.

And so, while we may embark on an extended theoretical project, identifying the multiple discrepancies and divergences between sociological and psychological notions of consciousness, the point - returning here to a consideration of Biko's work - is that the psychological dimension must be understood in an ordinary sense, that is, in terms of everyday experience, subjectivity, consciousness, as they are - or might come to be - articulated via a political awareness of the need for consolidated black solidarity in the face of white supremacy. This connection between material conditions and the development of consciousness is precisely Biko's (1978) point in speaking of Black Consciousness, in which the role of a type of vernacular materialist psychology is not negligible. The same can be said of Fanon's (1986) use of phenomenology in Black skin white masks: to take seriously the stuff of subjective experience is not necessarily to perform a reductive analysis or to distance ourselves from a materialist form of political critique. Hence, furthermore, the imperative Gordon (2000) asserts in respect of an anti-racist African philosophy: the need for detailed exploration of the lived experience of blackness. ${ }^{2}$

Mabogo More's (2008) influential work on Biko helps extend our discussion of a political consciousness. More contextualizes Biko's writings on the tradition of African

\footnotetext{
We might align Biko's use of conscientization with the aims of a Marxist psychology of everyday life, as articulated by Hayes (2001). In calling for a greater critical awareness of everyday experience, Hayes is well aware of the pitfalls of psychological individualism, along with those of traditional modes of phenomenological psychology, which eschew theory "in hope of understanding human experience through the uncontaminated, extended descriptions of human lives" (2001: 50). He nevertheless argues: "The argument for a (materialist) psychology of everyday life is not to suggest that this is achieved simply through the detailed account of the uniqueness of particular individuals. The concrete materiality of individuals' lives must be sought in the situatedness of lived experience, as well as in the dialectical development of a theoretical [or political] language able to explain the contradictions of everyday lived-experience" (Hayes, 2001: 50).
} 
existentialist philosophy, which, he says, deals with: "the emergence of black selfhood, black suffering, embodied agency, freedom, bad faith, racism, and liberation; in short ... with being-black-in-the-world" (More, 2008: 47). In an anti-black society such as South Africa, states More, developing and adding philosophical texture to Biko's analysis, there are two modes of human existence, each of which is the product of reflective consciousness: being-white-in-the-world (white consciousness) and being-black-in-the-world (black consciousness). These two modes of being are dialectically related; althoughcontradictory, theyareneverthelessmutually-dependent. This is not however to imply a symmetrical relation: white consciousness has through various economic, legal, religious, political means "subjugated and controlled black self-consciousness thus denying blacks their existential freedom" (More, 2008: 50). The emergence of Black Consciousness

"was therefore a response to white consciousness that sought to appropriate and dominate the consciousness and thus the freedom of black people. It was and still is a struggle for a new consciousness, a reawakening of a self-consciousness, a re-appropriation of black self-consciousness from the clutches of an appropriative and dominating white consciousness a rediscovery of the black self which lay buried beneath white consciousness imposed by blacks by cultural, political, economic, linguistic and religious domination. It is, so to speak, an 'affirmative action' on the self by the self, an affirmation not from the Other but from and by the self". (More, 2008: 50)

This masterful description simultaneously isolates the psychic dimension of political consciousness ("reawakening ... self-consciousness", "action ... on the self by the self") whilst nevertheless locating it in a particular historical frame ("dominating white consciousness"). The struggle for a new consciousness (being-black-in-the-world) is again shown to involve an indispensable psychological dimension. This much is evident also in Biko's description of how Paulo Freire's (1990) notion of conscientization came to be operationalized within Black Consciousness as a type of protest talk (Wilson, 1991). For Biko (1978: 114), conscientization involves the repeated attempt to

"make reference to the conditions of the Black man and the conditions in which the Black man lives. We try to get Blacks in conscientization to grapple realistically with their problems ... to develop what one might call an awareness, a physical awareness of their situation ... to be able to analyze it, and to provide answers for themselves".

Warning against a view that would consign such activities to mere exercises in mental liberation, Mngxitama (2008: 4) reiterates that in all articulations of conscientisation “'action' or 'struggle' is key ... [Black Consciousness] is about total liberation, from 
material, spiritual, cultural, political power .... [it is] not some meditative process outside real existence". That is to say, the mental dimension of conscientization is not somehow peripheral to but is rather a fundamental aspect of grounded political praxis.

It is a commonplace of Fanon scholarship to note the bricolage component of his work, namely the fact that he drew together a variety of conceptual resources (from phenomenology, existentialism, psychoanalysis, philosophy, the language of psychiatry, etc.) to fashion a novel language of critique irreducible to any of its component parts. We can appreciate something of a similar impetus in Biko's - and by extension, Sobukwe's - writing, that is, a borrowing of terms not previously prioritized in political discourse precisely to the ends of rejuvenating an otherwise moribund - or fatally flawed - mode of political engagement. In short, the value and distinctiveness of the psychological vernacular as deployed by Biko and Sobukwe alike has much to do with how effectively it calls attention to (psychosocial) aspects not adequately foregrounded by foregoing political vocabularies.

In bringing this section to an end, let me reiterate that Biko was using "consciousness" and aligned psychology concepts (identity, mentality, self-confidence, self, etc.) not for the purposes of scholarly or philosophical abstraction, but for their immediate ready-to-hand political use. If the opposing argument is that Biko's use of these concepts is not properly psychological, then that is precisely the point: they have been subjected to a 'psychosocial' application which renders them politically operative within their given political context. If this is an all too worldy or too secular a usage of psychological concepts - to employ terms Edward Said (1983) uses in criticizing abstruse modes of scholarship cut off from political reality - then, we might say, this is so much the worse for psychology. ${ }^{3}$

\section{Biko/Sobukwe/Lembede}

In histories of African political thought in South Africa, Sobukwe's name often appears as the joining term in a historical sequence beginning with Anton Lembede and ending with Biko (Gerhart, 1978). This lineage is notable for a number of reasons. For a start, there is a remarkable continuity of ideas here, from Lembede in the early 1940s, to Sobukwe in the 1950s, and then Biko in the late 1960s and 1970s. The case can be made, for example, that crucial facets of what Biko has in mind with the idea of Black Consciousness as viable cultural and political identity, are already present in Sobukwe's writings of the 1950s. Secondly, these three leaders represented an unrepentant African Nationalist/ Black Consciousness stance located definitively outside a Congress tradition. (The fact of the overwhelming ideological affinity between these two movements warrants their being grouped together, despite the approximately twenty year gap separating

Interestingly, what Said (1983) calls for in order to combat the cult of academic specialization, is precisely an amateurism of approach which avoids the retreat of intellectual work from the actual society in which it occurs. 
the emergence of the former from the latter). Such a stance maintained, thirdly, a vital psychological dimension, deploying a vernacular form of the psychological, a ready-tohand political use of psychological concepts. This "psychological" component is evident in the degree to which Biko, Sobukwe and Lembede stress the debilitating effects of internalised racism, firstly, and in respect, secondly, of how each advocated a posture of autonomy and non-reliance, a pronounced emphasis thus on an independent African (or Black) form of cultural identity.

There are two ways then in which we can demonstrate the psychosocial relevance of Sobukwe's thought in what follows. By pointing to the overtly psychological pronouncements in his own writings, firstly, and, secondly, by attending to the aligned psychological dimension in the work of Lembede and Biko, whose writings respectively precede and extend many of his own key preoccupations. Although I cannot undertake a systematic analysis here of the various interlinked psychological components within the work of these three intellectuals, we can briefly highlight a series of key moments in this lineage of ideas.

\section{Black Consciousness before Black Consciousness}

"Sobukwe and his colleagues" write Karis \& Gerhart (2013: 123), "following the approach taken by Lembede, based their thinking on the premise that the African's most fundamental weakness was a psychological one". Malaika wa Azania (2014) similarly observes: "It was Sobukwe who posited the argument later refined by Biko, that years of white supremacy had conditioned whites to be dominant and blacks to be submissive and because of this, blacks needed, above all, psychological independence".

There are of course important historical precedents to Sobukwe's arguments, including Pixley ka Seme's "Regeneration of Africa" speech at Columbia University in 1906, John Dube and Sol Plaatje's debates at the forming of the South African Native National Congress in 1912, and Lembede's African Nationalist writings of the early 1940s. Nevertheless, given Sobukwe's role in revitalizing such debates, and the echo-effect that obtains between his political pronouncements and Biko's, we must allow wa Azania's characterization of Sobukwe's importance to stand.

Biko memorably states that "The most potent weapon in the hands of the oppressor is the mind of the oppressed" (1978: 92). He adds to this a less frequently cited passage:

"If one is free at heart, no man-made chains can bind one to servitude, but if one's mind is so manipulated and controlled by the oppressor as to make the oppressed believe that he is a liability to the white man, then there will be nothing the oppressed can do to scare his powerful masters". (Biko, 1978: 92) 
These words bear comparison with Sobukwe's own thoughts on the necessity for a "mental revolution" (1959/2013c: 506) amongst Africans, published some twenty years earlier:

"The white minority can maintain its continued domination only by perfecting the techniques of control in such a way as to enlist the active cooperation and goodwill of the oppressed. These techniques include the ... condition[ing of] the minds of the dominated for the unquestioning acceptance of their role as collaborators in the perpetuation of their own domination".

To this we should add a comment that Sobukwe makes in his famous 1949 speech as President of the Students' Representative Council, to the Completers' Social at Fort Hare. Quoting the words of Marcus Garvey, he remarks: "You cannot grow beyond your thoughts. If your thoughts are those of a slave, you will remain a slave" (Sobukwe, cited in Pogrund, 2012: 36).

Both Biko and Sobukwe stress the factor of psychological control, pointing, furthermore, to a foreclosure of agency which is simultaneously structural and yet also, nevertheless, subjective. Although they do not explicitly utilize the term (Biko comes close), the longstanding philosophical - and psychosocial - problematic of voluntary servitude informs their respective analyses. The reversal of this foreclosure, the undoing of psychological servitude, becomes thus a precondition to any meaningful political agency.

Seepe (2008) extends the point at hand: for both Sobukwe's Pan-Africanism and Biko's subsequent Black Consciousness change "was also based on the individual and promoted ... the full development of the human personality". Involvement in the struggle, furthermore, "meant a life-changing and life-affirming exercise that would strengthen people's resolve for freedom ... help[ing] them actively plan a different future" (Seepe, 2008).

Just as we may detect the echo of Sobukwe in Biko, so we may discern Lembede's ideas in many of Sobukwe's formulations. For Lembede (1996), the material dispossession of colonial subjugation brings with it a series of damaging psychic effects, including an incipient sense of self-hatred, feelings of resignation and defeatism, and a general state of moral degradation. Fatton (1981: 115) outlines Lembede's argument:

"Africans developed such an acute sense of inferiority that their colour had become a symbol of sin, their history an episode of savage barbarism, and their culture a badge of backwardness and ignorance ... Africans had espoused the norms and values of 
the colonizer; they had come to believe that civilization meant the 'whitening' of their soul and the rejection of their blackness".

Lembede (1996: 92) uses explicitly psychological language to characterize the malaise of spirit induced by colonialism:

"Moral and spiritual degeneration manifests itself in such abnormal and pathological phenomena as loss of self-confidence, inferiority complex, a feeling of frustration, the worship and idolisation of [the] whitemen, foreign leaders and ideologies. All these are symptoms of a pathological state of mind ... the panacea of all these ills is National Freedom".

Furthermore:

"The African has lost or is losing the sterling qualities of self respect, self-confidence and self-reliance ... I stand against this psychological enslavement of my people. I strive for the eradication of this 'Ja-baas' mentality, which for centuries has been systematically ... implanted into the minds of Africans". (Lembede, cited by Msumza \& Edgar, 1996: 24).

It is worth noting here not only the aptness of Lembede's description - rarely, by the mid-1940s, had the psychic effects of colonial power been so adeptly expressed, certainly within South Africa - but the date at which he was writing. These words, drafted in 1946 for the "Policy of the Congress Youth League", appeared 6 years before even the 1952 French publication of Fanon's Black skin, white masks (1986), a text often credited with developing the canonical formulations of many of the above sentiments. If Fanon's text is so often credited with being at the origin of attempts to formulate a progressive critical psychology of the postcolonial, then we now have reason to stress the role of an earlier and distinctively southern African voice.

Lembede's position is enthusiastically endorsed by Sobukwe. Paraphrasing Sobukwe, Karis \& Gerhart (2013: 123) note that the African's most fundamental weakness was a psychological one:

"Africans ... had to abandon their slave mentality and begin to believe in the inherent worth of their own people. Shame and the habit of dependence had to be replaced by pride and self-confidence ... the fundamental task of African leadership was to achieve such a mental transformation among the masses through the preaching of African Nationalism - the building of a nation". 
Here are to be found one of the prospective causes for the subsequent split between the ANC on the one hand, and Sobukwe and his fellow Africanists on the other. For Sobukwe and his comrades, the urgent need for a mental revolution to combat the pernicious effects of apartheid mentality necessitated the prioritization of African Nationalism. There are other reasons also, of course - the Africanist's assertion of Izwe Lethu, the claim that the land belongs to Africans rather than all who live in it - and yet the factor of a proposed mental revolution is, arguably, co-extensive with such claims of African sovereignty, and not thus to be considered of lesser importance.

\section{Apartheid mentalities}

The psychosocial dimension to Sobukwe's thought involved not only the imperative to consolidate a viable cultural and political (African) identity, but the need also to challenge various insidious forms of apartheid mentality. A further facet of Sobukwe's influence on the development of Black Consciousness comes to the fore here, namely his non-collaborationist opposition to the role of white liberals in anti-apartheid activities. ${ }^{4}$

"Sobukwe", says Seepe (2008), challenged the "supremacy and arrogance of liberal whites in determining and shaping the black people's struggle against racial oppression". This Sobukwe and Biko most certainly have in common: the unwillingness to concede that there are some "good whites" who are not in the oppressor camp. In the January 1959 edition of The Africanist Sobukwe responds to the question "Do you regard all whites as oppressors?":

"We regard them all as shareholders in the S A Oppressors Company (Pty) Ltd. There are whites, of course, who are intellectually converted to our cause, but because of their position materially, they cannot fully identify themselves with the struggle of the African people. They want safeguards and check-points all along the way, with the result that the struggle of the people is blunted, stultified and crushed". (1959/2013b: 473)

Furthermore, in terms that would later be explicitly echoed by Biko, Sobukwe states:

"From past history ... we know that a group in a privileged position never voluntarily relinquishes that position. If some members of the group appear to be sympathetic to the demands of the less-privileged, it is only in so far as those demands do not threaten the privileges of the favoured group. If they (the privileged) offer assistance, it is for the purposes of 'directing' and 'controlling' the struggle of the underprivileged and making sure that it does not become dangerous". (2013b: 472)

\footnotetext{
For Sobukwe there is a distinct difference between liberals and Marxists in terms of the broader relationship of white people to white supremacy (the latter, as opposed to the former, sometimes being the source of valuable theoretical forms of critique). In Biko, these distinctions fall away and white liberals come to include everyone from Albie Sachs, Raymond Suttner, Joe Slovo, etc. Biko uses "white liberals" as an umbrella term for all sympathetic white people that claim solidarity with Black people's struggles. I owe this qualification to Terblanche Delport.
} 
The psychosocial implications of such a non-collaborationist standpoint were at least twofold. Firstly, it accentuated the political agency of African men and women themselves, by placing responsibility for the fight against apartheid squarely with them, and them alone, a move which anticipates the later Black Consciousness slogan: "Back man, you are on your own". Secondly, it called into question any implicit endorsement of the apartheid system, and, along with it, the (unconscious) adoption of the passivity of the victim. In other words, to do nothing, to accept the apparent "normality", the status quo of apartheid, was to be complicit with the system.

To in any way negotiate with, make requests from, or tacitly confer authority upon the apartheid government, was anathema to Sobukwe. His concern with in any way legitimizing the white supremacist system extended even to the case of receiving insults. Bearing the brunt of racist insults or indignities in a resigned manner could in its own way be said to reaffirm apartheid's racist system of values. In the forward to the December 1957 issue of the Africanist Sobukwe announced that in the forthcoming year the problem of status would be paramount:

“[O]ur immediate battle is for 'STATUS' .... having discovered that in liberatory struggles, it is the accumulation of small victories which builds up the confidence of the masses and imbues them with a sense of the inevitability of victory, we propose, for 1958, a campaign against the appellations by which the Herrenvolk [master race] are pleased to know us. Next year we are going to put a stop to the terms 'Boys' and 'Girls' which are so ungrammatically used by white South Africans ... We will no longer have 'Jack', 'George', 'Nancy', 'Jane', etc. as handy labels to be attached to any black man or woman by any white man or white women, white boy or white girl". (2013a: 464)

The status campaign - of particular historical significance given that it was first official PAC campaign - was as much a refutation of racist objectifications as it was an insistence on the dignity and the cultural and indeed subjective identity of those denigrated by apartheid. The twin imperatives of the campaign were, following Karis \& Gerhart (2013), the exorcising of a slave mentality and an assertion of the African personality. In Sobukwe's own words:

"We are reminding our people that acceptance of any indignity, any insult, any humiliation, is acceptance of inferiority. They must first think of themselves as men and women before they can demand to be treated as such ... [We must] free the mind of the African". (Sobukwe, cited in Pogrund, 2012: 109)

Political activity should not as such be articulated along the lines of a requested act of goodwill, or take the form of an appeal to the oppressor. The switch-over from what one 
might call a cap-in-hand protest tradition to a more assertive political and subjective style - something else Black Consciousness would inherit from the Africanists - is notable: "[W]e are not begging the foreign minorities to treat our people courteously. We are calling on our people to assert their personality. We are not hoping for a change of heart on the part of the Christian oppressor". (Sobukwe, 1959/2013c: 506).

This is not only a statement of intent and a qualification of political strategy, it is also a comment directed against the Congress protest tradition, hitherto characterised - certainly according to Karis \& Gerhart (2013) - by its adherence to Christian principles, moderate modes of action, and the hope for reconciliation between the races.

Pheko (2012) stresses the radicalism of Sobukwe's position relative to the ANC politics of the day:

"Anton Lembede, Ashby Peter Mda and Sobukwe were among the leading revolutionaries who adopted the 1949 Programme of Action and stated that 'African people claim the right to self-determination'. It moved far beyond the previously tepid calls for changes to discriminatory legislation but rather demanded political independence and liberation from white domination".

Mabandu (2013) similarly calls attention to this rupture, apparent first in the departure of the Youth League from the general policy in the 1940s, and then in the more dramatic PAC breakaway from the ANC in 1959. In Sobukwe, Mabandu says, we see the ideas of dignity and African selfhood. Moreover, according to Mabandu (2013):

"It was first Sobukwe's remarkable Pan-Africanist break with the apologist mould of the ANC's black Englishman-ism, a political posturing marked by the mimicking of all things British as a way of showing the then coloniser that they were like him. This apologist politics were defined by pliable deputations but hardly any real challenge to the oppressor".

Historians will tell us that the Africanist break concerned more than just a shift from an apologist politics - the rejection of the ANC's multiracial alliance in favour of policies prioritizing African sovereignty, national identity and African ownership of the land all being key factors here - and yet, such a psychological break, as argued above, was an instrumental component of such policy commitments. Moreover, even if one does not fully agree with Mabandu's characterization of the ANC's political posture in the 1940s and 1950s, one can nonetheless appreciate the point being made: a sea-change in political attitude, a prospective mental revolution, was brought about by the departure of the Africanists from the ANC. 
We are better placed then to understand why a vernacular "psychology" of sorts played such an indispensable role not only for Lembede, Sobukwe and Biko, but also more generally for the forms of African Nationalism, Pan-Africanism and Black Consciousness that each man represented. If we accept the above positions of Pheko and Mabandu, namely that earlier Congress opposition was premised largely on the hope of a multiracial alliance that would inevitably favour the values of the dominant culture of the oppressor, then such terms of "resistance" would simply re-inscribe a pattern of dominance and subordination at a different level.

Such a gradualist approach, contested always on the oppressor's terms, enables little by way of an autonomous identity of resistance. Any such identity remains contingent on the dominant group, from whom concessions must be begged, and via whom one is forced to define one's self always as - to paraphrase Sartre's famous phrase attacked by Fanon (1986) - the minor term in a larger dialectical progression. A relation of this sort provides no room with which to engender anything like the notions of self-sufficiency, autonomy, or pride so crucial in breaking conscious and unconscious bonds of subservience and submissiveness.

Hence the insistence shared by Lembede, Sobukwe and Biko on the need to consolidate a form of identity, be it via African Nationalism or Black Consciousness, which was rooted in the resources of African culture, alongside the related ambition of forging a solidarity of the oppressed existing apart from - and in opposition to - political alliances that inevitably favoured the interests of white liberals or communists.

Before drawing this section to an end, let us turn briefly to Ditshego, whose brief sketch of Sobukwe's key political contributions concurs with that presented above:

"Sobukwe was instrumental in formulating PAC policies ... some of those policies are to unite and rally the African people around African nationalism and to espouse the African personality ... [T] he personality of a people can only refer to their cultural personality or cultural identity, which is made up of three interrelated factors: selfconsciousness, the linguistic factor and the historical factor. All three are important". (Ditshego, 2015)

I include Ditshego's comments here to stress what is crucial both for a psychosocial approach and for an adequate political appreciation of Sobukwe's work, namely the fact that the "psychological" conceptualizations developed above are always dynamically - and inseparably - inter-related with culture, language and history. This proves an instructive reminder for psychosocial studies: any psychological notions of genuine political value are invariably of a materialist (historically-situated, 
"worldly", experientially-grounded) as opposed to an idealist (purely theoretical or disciplinary) sort.

The information I have assembled above supports the claim that the psychosocial elements of Sobukwe's thought, the fact that African Nationalism and Black Consciousness alike entail "psychological" notions (mental emancipation, the African personality, psychological enslavement, consciousness, etc.), is not merely of passing scholarly interest, but is of essential importance to these aligned political movements. This psychological component concerns us here not simply because of the overlap with the themes of a materialist psychology (Hayes, 2001; Parker, 2015), but because it was a crucial factor in ensuring a mental emancipation, that is, in ensuring the break with the more moderate protest tradition of the ANC of the day. Indeed, the other facets in this decisive break (the ideals of African sovereignty and nation-building over those of a multiracial alliance, the proclamation of Iswe Lethu, etc.) need to be read in tandem with the radicalism of this commitment to a revolution in consciousness.

\section{Conclusion}

The language of both Sobukwe's and Lembede's African Nationalism, like that of Biko's Black Consciousness, is shot through with a type of strategic vernacular use of psychological concepts. We see this time and time again, in Lembede's reference to the various cultural and subjective states engendered by colonial subjugation (pathologies of mind, inferiority complexes, moral degradation, defeatism, etc.). It is likewise apparent in Sobukwe in terms of what needs to be confronted (conditioned submissiveness, complicity in one's own oppression) and overturned (by a mental revolution, in which cultural and historical pride, dignity and humanity are attained in the form of an African personality). This seems an exemplary historical case of a strategic and political utilization of psychological concepts within a psychosocial register of critique articulated to the ends of opposing colonial and white supremacist forms of oppression.

Such psychological concepts are of course no longer merely psychological, but have been transformed - they are "travelling" concepts, to once again draw on Edward Said (2000) - in order to do a different kind of practical (and indeed political) work. This could be given as a mandate of psychosocial studies as such: the attempt to develop new concepts, novel forms of critique derived from everyday political consciousness which bypass the confines of disciplinary insularity and enable us to highlight points of fixity and stasis that impede or enable political change.

I have argued that the revolution in political sensibilities that Sobukwe, Lembede and Biko treated as of central importance necessitated a conjunction of the psychological and the political. This, as I have tried to show, was an irreducible component in the new 
forms of self-assertion, political pride, and independent national identity (of, indeed the African personality), that was so vital in the Africanist break with the apologist approach of the ANC of the time. While this is obviously not the time to launch a comparative analysis of the political theorizations and strategies of the Congress movement as opposed to those of the Africanists and the proponents of Black Consciousness who stood outside it, we might nevertheless pose a critical hypothesis here.

The topics of consciousness and a variety of associated psychosocial conceptualizations and imperatives (mental emancipation, psychological enslavement, Biko's envisaged self, the African personality, etc.) do not feature in Charterist discourse to anywhere near the same extent as they do in the political vocabularies of African Nationalism and Black Consciousness. This is a fact which sets the latter aside, and, certainly in the terms of the argument developed above, assures the more radical emancipatory aspect of the latter over the former. We might put this more simply, by saying that a rudimentary form of psychosocial conceptualization was crucial in advancing the terms of the struggle against white supremacy. If this was the case, and if it is true also that for a great majority the struggle for liberation continues still today, then surely such an attention to conjunctions of the psychological and the political, still has its place.

\section{Acknowledgements.}

I am indebted to the review comments of Grahame Hayes, and particularly to those of Terblanche Delport, whose critical and historical input greatly improved the overall quality of this paper.

\section{References}

Akin-Ogundeji, O (1991) Asserting psychology in Africa. The Psychologist: Bulletin of the British Psychological Society, 4, 3-4.

Akin-Ogundeji, O (1993) Psychology in Africa. The Psychologist: Bulletin of the British Psychological Society, 6(11), 489-90.

Arnold, M (1979) Steve Biko: Black Consciousness in South Africa. New York: Vintage. 
Bhabha, H K (2004) Forward: Framing Fanon, in Fanon, F (2004) The wretched of the earth. New York: Grove Press.

Biko, S (1978) I write what I like. London: Bowerdean.

Blackman, L, Cromby, J, Hook, D, Papadopoulos, D \& Walkderdine, V (2008) Creating subjectivities. Subjectivity, 1, 1 -27.

Bowman, B, Duncan, N \& Sonn, C (2010) Towards a psychology of South Africa's histories: Living with and through the Apartheid Archive. South African Journal of Psychology, 40(4), 365-369.

Brown, S \& Stenner, P (2009) Psychology without foundations: history, philosophy and psychosocial theory. London: Sage.

Bulhan, H A (1979) Black psyches in captivity and crisis. Race \& Class, XX(3), 243-261.

Bulhan, H A (1985) Frantz Fanon and the psychology of oppression. New York \& London: Plenum Press.

Bulhan, H A (1999) Revolutionary psychiatry of Fanon, in Gibson, N C (ed) (1999)

Rethinking Fanon: The continuing dialogue. New York: Humanity Books.

Burton, M \& Flores Osorio, J M (2011) Introducing Dussel: The philosophy of liberation and a really social psychology. PINS (Psychology in society), 41, 20-39.

Butler, J (1997) The psychic life of power: Theories in subjection. Stanford, CA: Stanford University Press.

Cooper, S (2013) Africanising South African psychology. Journal of Black Psychology, 39(3), 212-222.

Cooper, S (2014) A synopsis of South African psychology from apartheid to democracy. American Psychologist, 69(8), 837-847.

Couve, C (1986) Psychology and politics in Manganyi's work: A materialist critique.

PINS (Psychology in society), 5, 90-130. 
Delport, T (2014) Ukuthi uyozala nkomoni. Paper delivered at UNISA event: "The historical and philosophical significance of Sobukwe and the African tradition", Pretoria, 2 September 2014.

Dladla, N (2014) Contested legacies: Sobukwe's Africanist conception of non-Racialism. Paper delivered at UNISA event: "The historical and philosophical significance of Sobukwe and the African tradition", Pretoria, 2 September 2014.

Ditshego, S (2015) If alive, what would Sobukwe say about 'The State of the Nation'. Mayihlomone News, 16 February 2105. http://mayihlomenews.co.za/if-alive-whatwould-sobukwe-say-about-the-state-of-the-nation/

Dubow, S (1995) Scientific racism in modern South Africa. Cambridge: Cambridge University Press.

Duncan, N. Stevens, G \& Sonn, C S (2012) Of narratives and Nostalgia. Peace and Conflict: Journal of Peace Psychology, 18(3), 205-213.

Fanon, F (1986) Black skin, white masks. London: Pluto (1952-French).

Fanon, F (1990) The wretched of the earth. London: Penguin (1961-French).

Foster, D (2004) Liberation psychology, in Hook, D (ed) (2004) Critical Psychology. Cape Town: University of Cape Town Press.

Fatton, R (1981) Class and nationalism in South Africa: A study of radicalization of black politics. Doctoral dissertation. University of Notre Dame, Indiana.

Frosh, S (2003) Psychosocial studies and psychology: Is a critical approach emerging? Human Relations, 56, 1547-1567.

Frosh, S (2011) Psychoanalysis outside the clinic: Interventions in Psychosocial Studies. London \& New York: Palgrave.

Frosh, S (2013) Psychoanalysis, colonialism, racism. Journal of Theoretical and Philosophical Psychology, 33(3), 141-154.

Frosh, S (ed) (2015) Psychosocial imaginaries: Perspectives on temporality, subjectivities and activism. London \& New York: Palgrave. 
Gerhart, G M (1978) Black power in South Africa: The evolution of an ideology. Berkeley, CA: University of California Press.

Gibson, N C (2003) Fanon: The postcolonial imagination. Cambridge: Polity Press.

Gibson, N C (2008) Black Consciousness after Biko, in Mngxitama, A, Alexander, A \& Gibson, N C (eds) (2008) Contesting the legacies of Steve Biko.

London \& New York: Palgrave.

Gordon, L R (1995) Fanon and the crisis of European man.

London \& New York: Routledge.

Gordon, L R (2000) Existentia Africana: Understanding Africana Existential thought. London \& New York: Routledge.

Halisi, C R D (1991) Black Consciousness philosophy, in Pityana, N.B, Ramphele, M, Mpumlwana, M \& Wilson, L (eds) (1991) Bounds of possibility: The legacy of Steve Biko \& Black Consciousness. London \& New Jersey: Zed Books.

Hayes, G (2001) Marxism and Psychology: A vignette. PINS (Psychology in society), 27, 46-52.

Hayes, G (2011) (Re-)introducing N Chabani Manganyi. PINS (Psychology in society), 41, 1-6.

Hayes, G (2014) The story of sociality: PINS (Psychology in society) at 30.

PINS (Psychology in society, 46, 15-20.

Hook, D (ed) (2004) Critical psychology. Cape Town: UCT Press.

Hook, D (2005) A critical psychology of the postcolonial. Theory and Psychology, 15(4), 475-503.

Hook, D (2012) A critical psychology of the postcolonial. London \& New York: Routledge.

Hook, D (2013) (Post)apartheid conditions: Psychoanalysis \& social formation. London \& New York: Palgrave. 
Hook, D \& Truscott, R (2013) Fanonian ambivalence: Psychoanalysis and postcolonial critique. Journal of Theoretical and Philosophical Psychology, 33(3), 555-169.

Howitt, D \& Owusu-Bempah, J M (1994) The racism of psychology: Time for change. London: Prentice Hall.

Karis, T G \& Gerhart, G M (eds) (2013) From protest to challenge: A documentary history of African politics in South Africa, 1882-1990, Volume 3: Challenge and violence, 1953-1964. Auckland Park: Jacana.

Kessi, S (2013) Re-politicizing race in community development. Using postcolonial psychology and Photovoice methods for social change. PINS (Psychology in society), 45, 19-35.

Lembede, A M (1996) Freedom in our lifetime: The collected writings of Anton Muziwakhe Lembede. Johannesburg: Skotaville.

Long, W \& Foster, D (2013) The changing face of "relevance" in South African psychology. PINS (Psychology in society), 45, 3-16.

Mabandu, P (2013) Ashiki dialogues: Reflecting ideas of Sobukwe and Biko. City Press, 24 March 2013. http://www.news24.com/Archives/City-Press/DashikiDialogues-Reflecting-ideas-of-Sobukwe-and-Biko-20150429

Macey, D (1999) Fanon, phenomenology, race. Radical Philosophy, 95, 8-14.

Macey, D (2000a) The Penguin dictionary of critical theory. London: Penguin Books. Macey, D (2000b) Frantz Fanon: A life. London: Granta.

Macleod, C \& Bhatia, S (2007) Postcolonialism and psychology, in Stainton-Rogers, W \& Willig, C (eds) (2007) The SAGE handbook of qualitative research in psychology. London: SAGE.

Mama, A (1995) Beyond the masks: Race, gender and subjectivity. London: Routledge.

Manganyi, N C (1973) Being-black-in-the-world. Johannesburg: Sprocas/Ravan Press. 
Manganyi, N C (1977) Mahangu's reverie and other essays.

Johannesburg: Ravan Press.

Manganyi, N C (1981) Looking through the keyhole: Dissenting essays on the black experience. Johannesburg: Ravan Press.

Manganyi, N C (1985) Making strange: Race, science and ethnopsychiatric discourses, in Barker, F, Hulme, P, Iversen, M \& Loxley, D (eds) (1985) Europe and its others. Colchester: University of Essex Press.

Manganyi, N C (2011) The violent reverie: The unconscious in literature and society. PINS (Psychology in society), 41, 7-19.

Mangcu, X (2012) Biko: A biography. Cape Town: Tafelberg.

Martín-Baró, I (1994) Writings for a liberation psychology.

Cambridge, MA: Harvard University Press.

Mngxitama, A (2008) Why Biko would not vote. New Frank Talk, 1, 2-26.

Msumza, L K \& Edgar, R R (1992) Introduction, in Edgar, R R \& Msumza, L K (eds)

Freedom in our lifetime: The collected writings of Anton Muziwakhe Lembede.

Cape Town: Kwela Books.

Ndlovu, S (2010) Deracialisation? What deracialisation? There's no end to race. PINS (Psychology in society), 39, 56-62.

Nzimande, B (1985) Industrial psychology and the study of black workers in South Africa: A review and critique. PINS (Psychology in society), 2, 54-91.

Owusu-Bempah, J M \& Howitt, D (1995) How Eurocentric psychology damages Africa. The Psychologist, October 1995, 462-465.

Parker, I (1999) Critical psychology: Critical links. Annual Review of Critical Psychology, 1, 3-18.

Parker, I (2002) Critical discursive psychology. Houndsmills: Palgrave Macmillan.

Parker, I (2015) Psychology after the crisis. Hove \& New York: Routledge. 
Persram, N (2013) Introduction to special issue on Post/Coloniality/Subjectivity. Journal of Theoretical and Philosophical Psychology, 33(3), 135-140.

Pheko, M (2012) Sobukwe's legacy still lives. City Press, 17 March 2012.

http://www.news24.com/Archives/City-Press/Sobukwes-legacy-still-lives-20150430.

Pogrund, B (2012) Robert Sobukwe: How can man die better.

Johannesburg: Jonathan Ball.

Ratele, K (2004) About black psychology, in Hook, D (ed) (2004) Critical psychology. Cape Town: UCT Press.

Ratele, K (2014) Psychology in society (PINS) and traditions: Back towards a critical African psychology. PINS (Psychology in society), 46, 50-58.

Richards, G (2011) Race, racism and psychology: Towards a reflexive history. Routledge: London and New York.

Said, E (1983) The world, the text and the critic. Cambridge: Harvard University Press. Said, E (2000) Travelling theory, in Bayoumi, M \& Rubin, A (eds) (2000)

The Edward Said Reader. London: Granta.

Sanders, M (2002) Complicities: The intellectual and apartheid.

Durham, NC \& London: Duke University Press.

Saville Young, L (2011) Research entanglements, race and recognisability:

A psychosocial reading of interview encounters in (post-)colonial, (post-) apartheid South Africa. Qualitative Inquiry, 17(1), 45-55.

Saville Young,L \& Jearey-Graham, N (2015) “They're gonna come and corrupt our children": A psychosocial reading of South African xenophobia. Psychoanalysis, Culture \& Society, 20, 395-413.

Seepe, S (2008) Sobukwe - legacy revisited. Accessed 28 July 2014 http://www.iol.co.za/news/politics/sobukwe-legacy-revisited-1.391095\#.U615631wbml 
Sobukwe, R M (1957/2013a) Forward to 1958!, in Karis, T G \& Gerhart, G M (eds) (2013) From protest to challenge: A documentary history of African politics in South Africa, 1882-1990, Volume 3: Challenge and violence, 1953-1964. Auckland Park: Jacana.

Sobukwe, R M (1959/2013b) Future of the Africanist Movement: Questions and answers by Robert Sobukwe, in Karis, T G \& Gerhart, G M (eds) (2013) From protest to challenge: A documentary history of African politics in South Africa, 1882-1990, Volume 3: Challenge and violence, 1953-1964. Auckland Park: Jacana.

Sobukwe, R M (1959/2013c) The state of the nation. Speech by Robert Sobukwe on National Hero's Day, in Karis, T G \& Gerhart, G M (eds) (2013) From protest to challenge: A documentary history of African politics in South Africa, 1882-1990, Volume 3: Challenge and violence, 1953-1964. Auckland Park: Jacana.

Soske, J (2014) The impossible concept: A genealogy of the non-racial. Unpublished paper, delivered at Wits Institute of Social and Economic Research (WISER), March. 2014.

Stevens, G, Duncan, N \& Hook, D (eds) (2013) Race, memory and the Apartheid Archive: Towards a transformative social praxis. London, New York \& Johannesburg: Palgrave \& Wits University Press.

Stevens, G \& Laubscher, L (2010) Editorial: Facing the Apartheid Archive. PINS (Psychology in society), 40, 1-7.

Turner, $L$ (2008) Self-consciousness as force and reason of revolution in the thought of Steve Biko, in Mngxitama, A, Alexander, A \& Gibson, N C (eds) (2008) Contesting the Legacies of Steve Biko. Palgrave, London \& New York.

Turner, L \& Alan, J (1978) Frantz Fanon, Soweto and American Black Thought. Chicago: News and Letters Press.

Truscott, R \& Hook, D (2014) Lessons from the postcolonial: Frantz Fanon, psychoanalysis, and the psychology of political critique, in Kinnvall, C, Capelos, T \& Nesbitt-Larking, P (eds) (2014) Palgrave handbook of global political psychology. London \& New York: Palgrave.

Vaughan, M (1991) Curing their ills: Colonial power and African illness. Stanford University Press: Stanford. 
wa Azania, M (2014) Why Robert Sobukwe is not dead. Sunday Independent, 23 February 2014.

Wilson, L (1991) Steve Biko: A life, in Pityana, N B, Ramphele, M, Mpumlwana, M \& Wilson, L (eds) (1991) Bounds of possibility: The legacy of Steve Biko \& Black Consciousness. London \& New Jersey: Zed Books.

Woods, D (1978) Biko. London: Penguin. 